\title{
The palaeogeographical background of Late Devonian storm events in the western part of the Holy Cross Mountains (Poland)
}

\author{
Aleksandra Vierek \\ The Jerzy Kukuczka Academy of Physical Education, Mikołowska 72A, 40-065 Katowice, Poland; \\ e-mail: a.vierek@awf.katowice.pl
}

\begin{abstract}
Late Devonian coarse-grained carbonate deposits in the Holy Cross Mountains were studied for possible storm depositional systems and catastrophic tsunami events, as it must be assumed that the investigated area was strongly affected by tropical hurricanes generated in the open ocean North of Gondwana. This assumption appears consistent with diagnostic features of carbonate tempestites at several places in the Holy Cross Mountains. Sedimentary structures and textures that indicate so are, among other evidence, erosional bases with sole marks, graded units, intra- and bioclasts, different laminations and burrowing at the tops of tempestite layers.

It has been suggested before that a tsunami occurred during the Late Devonian, but the Laurussian shelf had an extensional regime at the time, which excludes intensive seismic activity. The shelf environment also excluded the generation of tsunami waves because the depth was too shallow. Additionally, the Holy Cross Mountains region was surrounded in the Devonian by shallow-marine and stable elevated areas: the Nida Platform, the Opatkowice Platform and the Cracow Platform to the South, and the elevated Lublin-Lviv area to the NE. Thus, tsunami energy should have been absorbed by these regions if tsunamites would have occurred.
\end{abstract}

Key words: carbonate tempestites, tropical hurricanes, tsunami, palaeogeography, Late Devonian, Holy Cross Mountains, Poland

\section{Introduction}

The Upper Devonian in the western part of the Holy Cross Mountains (HCM, Fig. 1A) is characterised by carbonate deposits. These are rhythmically stratified, thin-bedded micritic limestones, marly shales and marly limestones, locally with a wavy to nodular-fabric. The diverse, mainly reef-derived coarse-grained deposits (from calcarenites to calcirudites, including both flat-pebble conglomerates and carbonate breccias) with many sedimentary structures contain intercalations of limestone/ marl deposits (Table 1).
Szulczewski (1968, 1971) described finegrained marly limestones as autochthonous deposits in deeper-water settings. In contrast, he considered (Szulczewski, 1968) the coarsegrained limestones to represent subaqueous mass-flow deposits and turbidites. Later, Szulczewski et al. (1996), Racki \& Narkiewicz (2000) and Vierek (2007a, b) suggested that storm surges affected the sedimentation in the HCM region. Earlier, Kaźmierczak \& Goldring (1978) had interpreted the flat-pebble conglomerates as high-energy deposits of tsunamis.

Flat-pebbles are particular deposits that have been described from various sedimenta- 


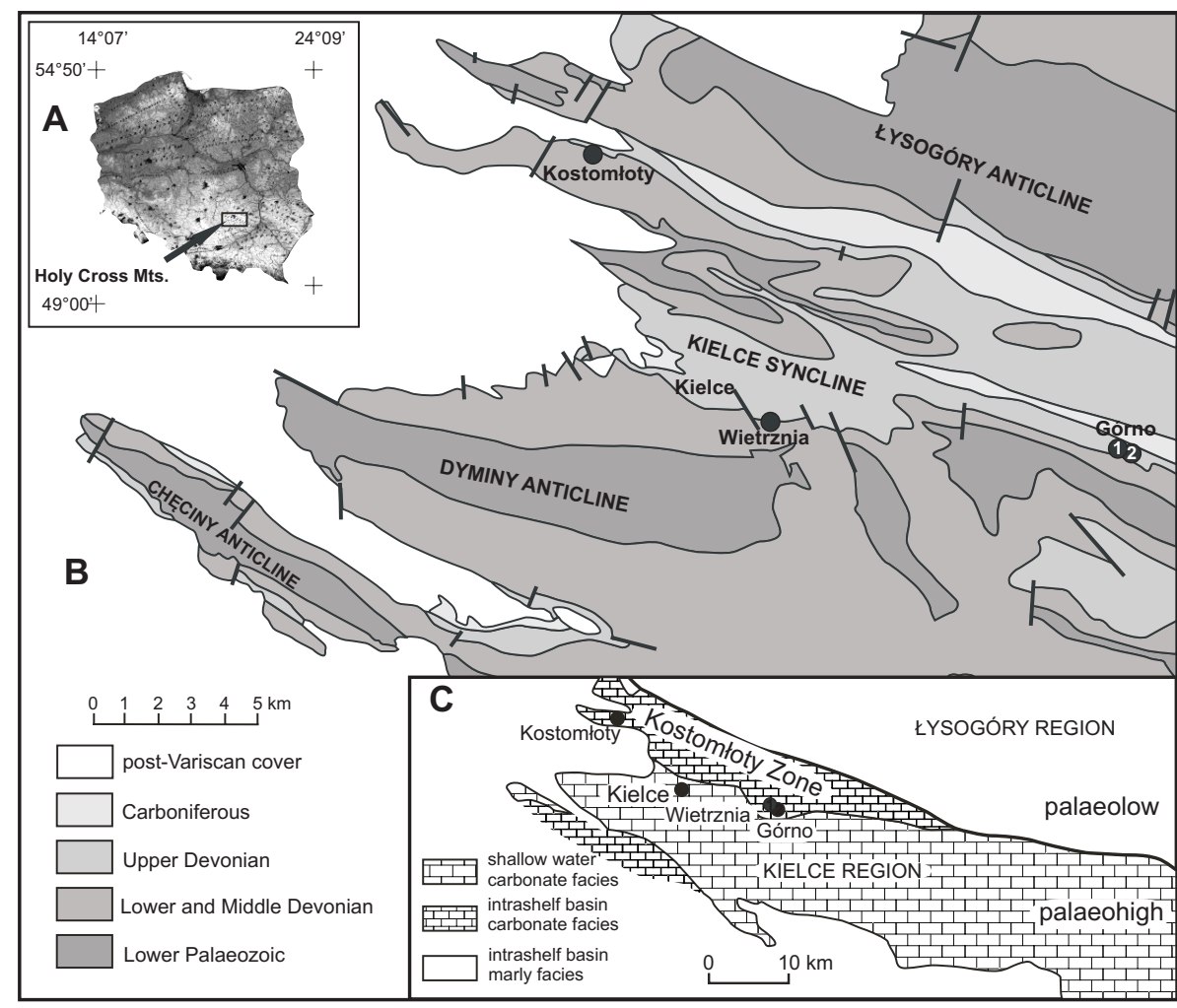

Fig. 1. Geographical, geological and palaeogeographical setting.

A: Location of the Holy Cross Mountains in Poland.

B: Simplified geological map of the western part of the Holy Cross Mountains (after Szulczewski, 1971).

C: Palaeogeography of the Givetian to Frasnian in the Holy Cross Mountains (after Racki, 1993) with the location of the Wietrznia, Kostomłoty and Górno outcrops ( 1 = Górno-field; 2 = Górno-Józefka). ry environments (e.g., Mount \& Kidder, 1993; Van Loon et al., 2012, 2013), and they are ascribed to various processes in diverse high-energy events. For example, deformation by cracks, a rare occurrence of such conglomerates, a high degree of scouring, and an angular character of the intraclasts may point at generation by occasional tsunamis (e.g., Pratt, 2002). In contrast, conglomerates composed of flat and (sub)rounded intraclasts with imbrication of pebbles and edgewise breccia fabrics may indicate storm-influenced sedimentation (e.g., Myrow et al., 2004) or submarine mass movements (e.g., Kullberg et al., 2001).

The different opinions and interpretations of the origin of the coarse-grained limestones in the study area require a closer examination. The interpretation and sedimentary record of storm/event deposits should be considered on the basis of palaeoclimate and palaeogeographical reconstructions. The present-day distribution of storm systems provides a basis for a palaeostorm model. It can be assumed that the environmental and meteorological conditions for generation of ancient tropical hurricanes or intense winter storms (see table 1 in Marsaglia \& Klein, 1983) were identical in the
Late Devonian as nowadays. The meteorological phenomena did not change fundamentally, and the palaeogeographical positioning of the continents is a key to the reconstruction of atmospheric circulation patterns and hurricane generation patterns in the geological past (e.g., Lloyd, 1982).

\subsection{Objectives}

The present contribution has three main objectives.

The first objective is to consider the occurrence of storm activity in the context of the palaeogeographical position and palaeoclimate conditions of the HCM during the Late Devonian. One should realise, however, that palaeogeographical data do not provide evidence, but only premises regarding possible storm activity. Only sedimentological analyses of the criteria that might indicate tempestites can confirm or reject an interpretation of storm deposits.

The second objective is to describe the features in the study area that might be diagnostic of carbonate tempestites. 
Table 1. Lithofacies of the sediments under study and their characteristics.

\begin{tabular}{|c|c|c|}
\hline lithofacies & location & description \\
\hline $\begin{array}{l}\text { marly shales, marly lime- } \\
\text { stones }\end{array}$ & $\begin{array}{l}\text { Wietrznia, Kostomłoty- } \\
\text { Mogiłki, Górno-Józefka; } \\
\text { locally Górno-field }\end{array}$ & $\begin{array}{l}\text { dark grey; thin-bedded (locally medium- to thick-bedded); } \\
\text { finely laminated; flat boundaries; locally organic matter; } \\
\text { fossil-poor }\end{array}$ \\
\hline $\begin{array}{l}\text { nodular to wavy-bedded } \\
\text { limestones }\end{array}$ & $\begin{array}{l}\text { Wietrznia, Kostomłoty- } \\
\text { Mogiłki, Górno-field }\end{array}$ & $\begin{array}{l}\text { grey; medium-to thick-bedded; marly or lime mudstones; } \\
\text { wavy and/or knobby in shape; in situ regular or irregular, } \\
\text { elongated and lenticular nodules (approx. } 12 \mathrm{~cm} \text { long); } \\
\text { marly matrix; stylolites }\end{array}$ \\
\hline $\begin{array}{l}\text { micritic limestones (calcis- } \\
\text { iltites) }\end{array}$ & all studied sections & $\begin{array}{l}\text { grey; thin- to medium-bedded (locally thick-bedded); } \\
\text { horizontal and wavy (or HCS) lamination: millimetre-scale } \\
\text { micrite and pel(bio)sparite laminae or pelsparite and } \\
\text { biopelsparite; bioturbations; normally graded; distinct and } \\
\text { smooth boundaries (or rare erosional base and undulating } \\
\text { top); locally amalgamated with coarse-grained limestones; } \\
\text { stylolites; locally bioturbated }\end{array}$ \\
\hline $\begin{array}{l}\text { fine-grained limestones } \\
\text { (calcarenites) }\end{array}$ & all studied sections & $\begin{array}{l}\text { grey; thin- to medium-bedded; moderate to well-sorted } \\
\text { packstone to grainstone; normally graded; horizontal or } \\
\text { wavy lamination; locally HCS and undulating top; sharp } \\
\text { erosional base with gently wavy to distinctly v- or u-shaped } \\
\text { depressions (in some cases boundaries are smooth and pla- } \\
\text { nar); geopetal infillings; rare bioturbation; (micro)stylolites }\end{array}$ \\
\hline \multicolumn{3}{|c|}{ coarse-grained limestones (calcirudites): } \\
\hline - breccia & $\begin{array}{l}\text { Wietrznia, Kostomłoty- } \\
\text { Mogiłki, Górno-field, rare } \\
\text { in Górno-Józefka }\end{array}$ & $\begin{array}{l}\text { light grey; thin- to thick-bedded; poor- to moderately sorted } \\
\text { grainstone/rudstone; irregular, subangular or subrounded } \\
\text { intraclasts (approx. } 6 \mathrm{~cm} \text { long); sharp and non-erosional or } \\
\text { erosional bases; sharp and flat upper boundaries; matrix- (or } \\
\text { grain-) supported; (micro)stylolites; amalgamation }\end{array}$ \\
\hline - flat-pebble conglomerate & $\begin{array}{l}\text { Wietrznia, Kostomłoty- } \\
\text { Mogiłki, Górno-field }\end{array}$ & $\begin{array}{l}\text { light grey; medium-bedded; poorly sorted; flat and tabular } \\
\text { pebbles (up to } 25 \mathrm{~cm} \text { in size); horizontally oriented (in thin } \\
\text { layers) or edgewise fabric (in thicker layers); normally (or } \\
\text { sporadically inversely) graded; often erosional base; geo- } \\
\text { petal structures; matrix-supported; rare (micro)stylolites }\end{array}$ \\
\hline - coquina & Górno-Józefka & $\begin{array}{l}\text { grey; thin- or medium-bedded; moderate- (or well-) sorted } \\
\text { grainstone/rudstone; sharp and erosional base with sole } \\
\text { marks (or rarely no distinct base); locally graded; horizon- } \\
\text { tal or wavy lamination at the top; grain- (or rarely matrix-) } \\
\text { supported; rare bioturbation; geopetal structures; stylolites }\end{array}$ \\
\hline
\end{tabular}

Finally, the third objective is to provide evidence for the existence or non-existence of the tsunami that was hypothesised by Kaźmierczak \& Goldring (1978).

\subsection{Geological setting}

The present contribution is based on compilation, review and analysis of published and unpublished sedimentological data. Four outcrops of the Upper Devonian were studied for the purpose in the western part of the HCM (Fig. 1B). Three of them (the Wietrznia succession, the Kostomłoty-Mogiłki and Górno-Józefka quarries) have been described earlier
(Vierek, 2007a, b, 2008, 2010). This new study focuses on the Górno outcrop.

The Wietrznia Hill is located in the south-eastern part of the town of Kielce (Fig. 1B). The exposed rocks form part of the southern flank of the Kielce Syncline. The carbonates of the middle Wietrznia Beds (= set $C$, Lower Frasnian Palmatolepis transitans Zone: Pisarzowska et al., 2006) developed in a transitional facies (according to Szulczewski, 1971) and are built mainly of micritic-marly (basin) and coarse-grained (reef-derived) deposits (Table 1). Some centimetre-thick, rhythmically stratified, locally laminated, platy bituminous micritic limestones, which in places are wavy bedded to nodular, are intercalated with 
marly shale partings (= basin deposits). Thicker (up to $0.75 \mathrm{~m}$ ) coarse-grained limestones (calcarenites and calcirudites) with intra- and bioclasts and commonly erosional bases as well as normal grading (= reef deposits), are second in frequency. Set $C$ shows normal lateral variations in lithology and bed thickness within a downslope fore-reef facies from west to east, toward a more distal facies, traced over a distance of approx. 160-180 m (Vierek, 2007b; Vierek \& Racki, 2011). The mainly storm-controlled proximal gradient is laterally characterised by gradual changes from coarse-grained tempestites, represented by a flat-pebble conglomerate fabric, to diluted muddy tempestites. The clast diameters and the number of coarse-grained layers increase westwards. Towards the east, more intercalations of micritic limestones and marly shales occur. This variation is accompanied by a gradual decrease in the thickness of the coarse-grained layers towards the E, and locally these beds may disappear completely. These carbonates were deposited mainly at a depth of 50-90 m in oxygen-depleted middle to distal slope settings (see fig. 5 in Vierek \& Racki, 2011).

The abandoned Kostomłoty-Mogiłki quarry is situated on the east side of the Kostomłoty Hill, a few kilometres NNW of Kielce in the NW part of the HCM (Fig. 1B). In the quarry, the upper part of the Szydłówek Beds (Lower Frasnian Palmatolepis transitans Zone: Racki et al., 2004) and the Kostomłoty Beds (Middle Frasnian punctata Zone with $A$. gigas to the hassi s.l. Zone with A. curvata: Pisarzowska et al., 2006) are exposed (Racki, 1985; Racki \& Bultynck, 1993). The lowermost part of the Kostomłoty-Mogiłki succession (= the upper part of the Szydłówek Beds) is characterised by intercalations of marly limestones and shales, in part strongly tectonically disturbed, with laminated and fine-grained limestones (calcisiltites to calcarenites). The first thicker coarse-grained conglomerate beds define the base of the Kostomłoty Beds. The lower part of the Kostomłoty Beds comprise fossil-poor, horizontally laminated limestones (calcisiltites) and marly shales, which in places show wavy bedding, with a few calcarenite and calcirudite layers (Table 1). According to Racki \&
Bultynck (1993) and Pisarzowska et al. (2006), both the Szydłówek Beds and the Kostomłoty Beds represent a deeper basin environment (= basin facies of Szulczewski, 1971) with mostly oxygen-depleted bottom conditions. As interpreted by Vierek (2010), the laminated calcisiltites, calcarenites and part of the calcirudites (including both flat-pebble conglomerates and breccias) were formed by storm activity and combined flows, and deposited on the upper or middle part of the slope of the carbonate platform.

The abandoned Gorno outcrop (the socalled Górno-field), which is located along the road from Kielce to Lublin and the big, active Józefka quarry on the Józefka Hill are located $1.4 \mathrm{~km} \mathrm{~S}$ of Górno village (Fig. 1B). In the eastern part of the Górno-Józefka quarry, the upper part of the Szydłówek Beds (Lower Frasnian Palmatolepis transitans Zone to Middle Frasnian Palmatolepis punctata Zone with A. gigas: Racki et al., 2004) is visible (Vierek, 2008). Just like in the Kostomłoty-Mogiłki succession, the Szydłówek Beds represent a deeper environment (= basin facies of Szulczewski, 1971). They are usually medium- and thick-bedded darkgrey, fossil-poor marly limestones and shales. A few intercalated thin- to medium-bedded calcarenites and coquinas contain abundant detritus of brachiopods and crinoids, and are characterised by erosional surfaces and graded bedding (Table 1). According to Vierek (2008), calcarenites and coquina beds, characterised by erosional bases with sole marks, horizontal lamination at the top and skeletal concentrations of crinoids and brachiopods, were deposited around the storm-wave base (SWB) and should be interpreted as tempestites.

In the exposed Frasnian limestones of the Górno-field, conodont data led Małkowski (1981) to distinguish five sets (A-E) ranging from the transitans to the Palmatolepis rhomboidea Zone. The present study concerns only set?C, which probably is equivalent to the Late hassi s.l to the Early rhenana Zone (Ziegler \& Sandberg, 1990). The deposits of Górno-field are characterised by alternating thin-bedded micritic limestones and/or marly shales, which in some places are wavy- to nodular-bedded or disturbed by synsedimentary tectonics, and by 
frequent thin- to medium-bedded calcarenites and calcirudites with intra- and bioclasts (brachiopods and crinoids). An erosional bottom surface, graded bedding and undulating tops are common (Table 1 ).

\section{Regional palaeogeographical setting}

During the Early Devonian, a new large supercontinent, Euramerica (also called Laurussia) was formed. This continent with extremely wide shelf areas was positioned at equatorial latitudes (e.g., Lewandowski, 2003). The outer part of the Laurussia shelf constitutes a complex system of carbonate platforms, intracratonic basins and intrabasinal highs, and extends from southern England through Belgium and the central part of Germany to southern Poland and Moravia (Bełka \& Narkiewicz, 2008). In Poland, epicontinental Devonian facies developed in a shelf area trending roughly NW-SE, with a variable width ranging from 150 to $600 \mathrm{~km}$ (Narkiewicz, 1988). This shelf formed part of an elongated pericratonic basin stretching from western Europe to the Ukraine.

According to the Late Devonian palaeoclimate reconstruction of Witzke (1990), SW to central Europe was situated south of the equator at $10-30^{\circ} \mathrm{L}$. New palaeogeographical reconstructions by Golonka (2000) show, however, that the Polish part of the Devonian shelf of Laurussia was situated around the equator at $5-10^{\circ} \mathrm{S}$ in the (sub)tropical zone (Fig. 2). The present area of the HCM region was located in the central part of the carbonate shelf, which was far away from the land and adjacent to the Holy Cross Fault (Pożaryski, 1986; Narkiewicz, 2007).

The palaeogeography of the Givetian to Frasnian in the HCM region shows two distinct palaeogeographical/tectonic regions (Fig. 1C): the northern Łysogóry region (a palaeolow) and the southern Kielce region (a palaeohigh; Szulczewski, 1971, 1977). Later research (Racki, 1993; Racki \& Bultynck, 1993) identified a separate Kostomłoty transitional zone between the shallow-water Kielce stromatoporoid/coral platform and the broadly-defined Łysogóry ba- sin. The Givetian in the Kielce region was characterised by an extensive biostrome-colonized platform. As the result of a global sea-level rise during the Early Frasnian, the widespread carbonate platform shrank to isolated reef complexes (the Dyminy reef of Narkiewicz, 1988; and the Dyminy reef complex of Racki, 1993). There were two main types of Frasnian reefs: stromatoporoid/coral reefs and microbial mud mounds. The Dyminy reef developed close to Kielce (over the northern marginal zone of the Kielce carbonate platform), where it attained a thickness of $200-300 \mathrm{~m}$. The core of reef, approx. $10 \mathrm{~km}$ in diameter (Narkiewicz, 1988), is composed of stromatoporoid/ coral limestones indicating a shallow-marine environment. On the other hand, drowned, poorly oxygenated deeper-shelf areas $(=$ intrashelf basins) surrounded the Frasnian Dyminy reef: the Chęciny-Zbrza Basin to the South and the Łysogóry-Kostomłoty Basin to the North (Racki, 1993; Szulczewski, 1995). The mud mounds developed in quiet water below SWB (Szulczewski, 1971; Racki, 1993). At the beginning of the Famennian, the platform was smaller than it had been before, and the Late Devonian epicontinental succession indicates continuous but punctuated drowning of an increasingly differentiated carbonate platform, which was completed in the Visean (Szulczewski, 1995).

\section{The Devonian climate}

The Devonian position of Euramerica has been reconstructed on the basis of numerous palaeomagnetic data (see, for instance, fig. 16 in Scotese \& McKerrow, 1990; fig. 6 in Kent \& Van der Voo, 1990; figs 12-13 in Torsvik et al., 1990; fig. 12 in Golonka, 2000; figs 11-12 in Golonka, 2007); the thus obtained reconstruction is in good agreement with Devonian palaeoclimate indicators. Likewise, the history of the Devonian reefs is generally considered as reflecting the palaeoclimate, which is interpreted to have been a warm greenhouse time-span (e.g., Golonka, 2000; Joachimski et al., 2009).

According to palaeoclimate reconstructions and palaeotemperatures calculated by Joa- 

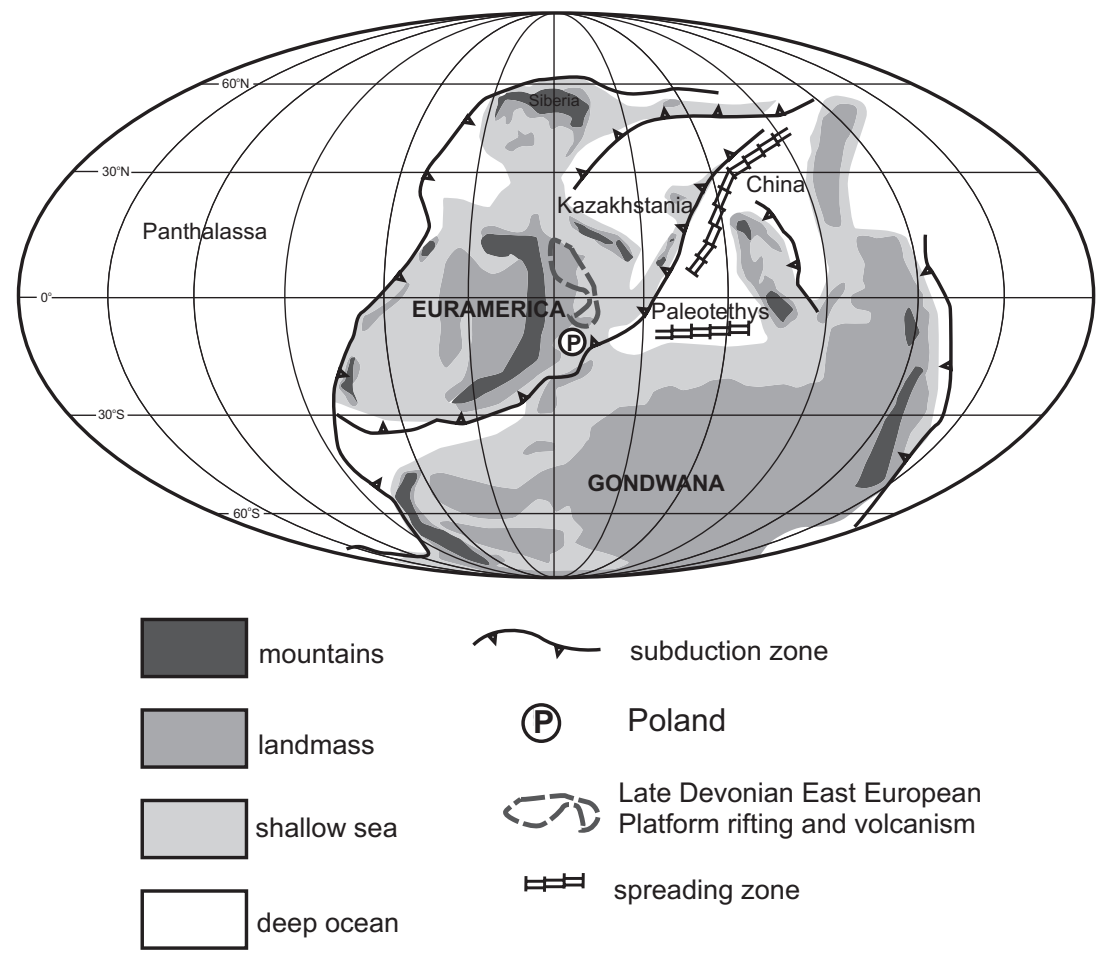

Fig. 2. Palaeogeographical reconstruction of the Late Devonian with the location of the southern part of the Polish Laurussian shelf $(\mathrm{P})$, of subduction zones, and of Late Devonian rifting and volcanism affecting the East European Platform (after Pujol et al., 2006).

chimski et al. (2009) from oxygen isotopes in apatite, the Early Devonian was characterised by warm temperatures of about $30^{\circ} \mathrm{C}$. A cooling trend started in the Pragian, with intermediate temperatures of $23-25^{\circ} \mathrm{C}$ for the Middle Devonian. During the Frasnian (Frasnian and Frasnian/Famennian transition; 383-375 Ma), temperatures increased again, with average warm tropical temperatures of about $30^{\circ} \mathrm{C}$. On the other hand, according to geochemical calculations of Pisarzowska (2009) for the Frasnian succession of the Wietrznia outcrop, the average temperature was $28^{\circ} \mathrm{C}$, and temperatures decreased between the Early and Middle Frasnian from $28^{\circ} \mathrm{C}$ to $23^{\circ} \mathrm{C}$.

In the marine environments, stromatoporoid/coral reefs flourished in the early Late Devonian (= Frasnian), building reefs in the HCM region (see above) and other areas (see Krebs, 1974; Kiessling, 2001; Kiessling et al., 2003; George et al., 2009). The reef ecosystem supports the reconstruction of warm tropical temperatures. In the present-day marine realm, the optimum temperature for the development of reefs ranges between $23^{\circ} \mathrm{C}$ and $29^{\circ} \mathrm{C}$; similar temperatures seem reasonable for the Devonian HCM environment. In addition, microbial reefs and mud mounds started to flourish during the Frasnian and were present in many areas (see, for example, Tsien, 1988; Whalen et al., 2002) as well as in the Holy Cross region (Szulczewski, 1971). As stressed by Joachimski et al. (2009), microbial reefs predominated during time-spans characterised by warm and very warm tropical sea surface temperatures - definitely with higher temperatures than the flourishing reef ecosystems characterised by rugose corals and stromatoporoids.

To sum up, the Late Devonian was characterised by greenhouse conditions and the study area was located in the southern tropics (Matyja, 1993; Kiessling et al., 2003).

A large ocean was present in the Early Devonian around the equator, covering half of the globe. The ocean was situated east of China and Gondwana. The eastern tropical winds generated warm surface currents. Tropical hurricanes therefore must have traversed around the eastern part of Gondwana and in a smaller sea between Laurussia and Kazakhstania, and between Laurussia and Gondwana (Marsaglia \& Klein, 1983). Major mixed hurricane/winter-storm zones were situated in both north-central and north-eastern Gondwana, southern Siberia and north-eastern China. 


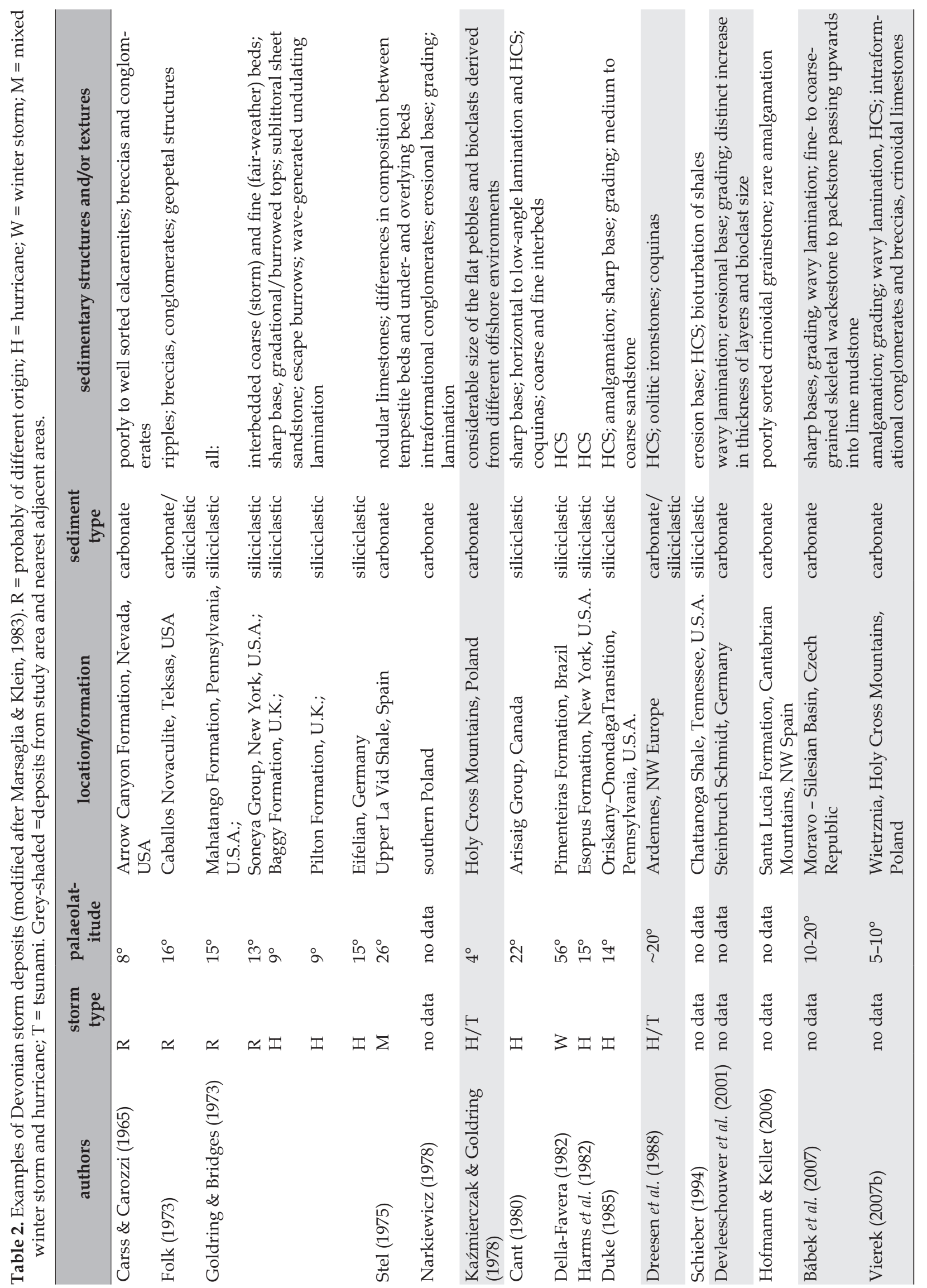


For the Middle and Late Devonian (Fig. 2 ), the palaeogeography of the oceanic realm between Laurussia and Gondwana is not entirely clear; it is presented as being either a narrow oceanic domain $(\sim 400 \mathrm{~km}$ : Lewandowski, 2003) or a wide ocean (to $3000 \mathrm{~km}$ : Tait et al., 2000). Apart from a wide oceanic domain between both margins, Laurussia and Gondwana, the areas were hurricane-influenced. This is confirmed by the Devonian sedimentary record (Table 2).

\section{Diagnostic features of tempestites}

Proximal tempestites represent storm deposits, formed by large waves and strong currents; they show evidence of disturbance of pre-existing sediments and rapid redeposition in shallow-water environments, and in deeper water below storm-wave base as diluted muddy tempestites ( =distal tempestites; e.g., Walker, 1984; Einsele, 2000; Flügel, 2004; Karim, 2007). As summarized by Aigner (1985) and Myrow \& Southard (1996), tempestites show much variation in thickness, grain size and in- ternal structures, depending mainly on a proximal or distal position (Monaco, 1992; Molina et al., 1997). In storm-affected basin fills, proximity criteria can be recognised at both lateral and/or vertical facies zones. In ascending order, ideal tempestites include: (1) sharp, often erosional bases with sole marks; (2) basal lags of coarse-grained reworked sediments, pebbles and skeletal grains; (3) graded basal parts overlain by parts with parallel laminae, hummocky structures, and/or cross-lamination; (4) mudstone units and post-event colonisation as well as reworking by organisms during following fair-weather intervals (Table 3).

Diagnostic features of tempestites and microfacies data in the Late Devonian deposits of the HCM have been described by the present author earlier (Vierek 2007a, b; 2010; Vierek \& Racki, 2011). As stressed by Vierek (2007a, b), frequent storm events and storm-generated flows were the main cause of erosion and redeposition of coarse-grained lithofacies in the Wietrznia succession. The particular sedimentological analysis of tempestites shows between 13 and 21 different-scale storm events (see the review in Vierek \& Racki, 2011, p. 6).

Table 3. Features of carbonate tempestites (after Aigner, 1985 and Myrow \& Southard, 1996) and their presence in the Wietrznia succession, Kostomłoty-Mogiłki quarry and Górno outcrops.

\begin{tabular}{|c|c|c|c|c|}
\hline tempestite features & $\begin{array}{l}\text { Wie- } \\
\text { trznia }\end{array}$ & $\begin{array}{c}\text { Kostom- } \\
\text { loty- } \\
\text { Mogiłki }\end{array}$ & $\begin{array}{l}\text { Górno- } \\
\text { Józefka }\end{array}$ & $\begin{array}{l}\text { Górno } \\
\text { field }\end{array}$ \\
\hline \multicolumn{5}{|l|}{ proximal: } \\
\hline - intra- and bioclasts & + & + & - & + \\
\hline - flat-pebble conglomerate & + & + & - & + \\
\hline - edgewise conglomerate fabric & + & + & - & - \\
\hline - amalgamation & + & - & - & - \\
\hline - lack of grading & + & - & - & + \\
\hline - channel fills & + & + & - & - \\
\hline \multicolumn{5}{|l|}{ normal/transitional: } \\
\hline - sharp, erosional base with sole marks & + & + & + & + \\
\hline - erosional contact between breccias and underlying micritic limestones & + & + & - & + \\
\hline - basal lag of coarse-grained reworked sediments, pebbles and skeletal grains & + & - & - & + \\
\hline - coquinas & - & - & + & + \\
\hline - graded unit & + & + & + & + \\
\hline - horizontal lamination & + & + & + & + \\
\hline - wavy lamination and HCS & + & + & - & + \\
\hline \multicolumn{5}{|l|}{ distal: } \\
\hline - increasing number of tempestite beds & + & - & - & - \\
\hline - thinner, finer and mud-dominated tempestite beds & + & - & - & + \\
\hline - sharp and planar base & + & + & + & + \\
\hline - lack basal lags & + & + & - & + \\
\hline - bioturbation and/or burrowing & + & + & + & + \\
\hline
\end{tabular}




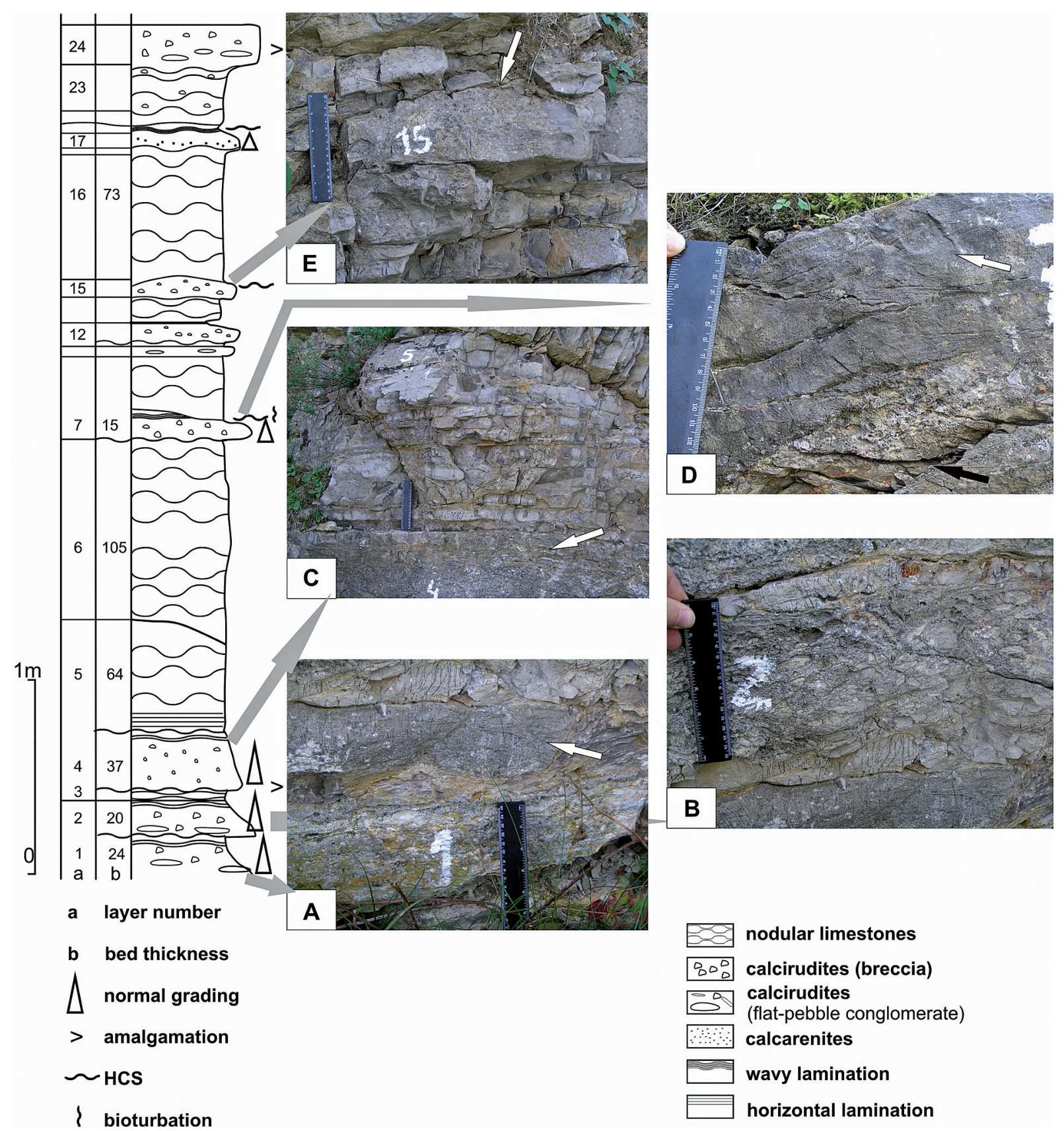

Fig. 3. The Górno-field exposure, with part of the succession (left).

A, B: Graded, conglomeratic and partly bioclastic layers (1 and 2); wavy lamination at the tops (arrow).

C: Thin-bedded micritic and partly nodular limestones; in the lower part graded calcarenites (layer 4) with cross-lamination at the top (arrow).

D: Tempestite layer 7 (compare Fig. 4 C) characterised by basal lags of coarse-grained reworked sediment and normal grading; black arrow shows erosional base with sole marks; the low-angle cross-lamination (white arrow) possibly represents part of hummocky cross-stratification.

E: Coarse-grained breccia with undulating top (arrow; layer 15).

Sedimentary structures and textures in the Kostomłoty Beds (Vierek, 2010) also shows that storms were likely the main causes of erosion of the Kielce carbonate-platform margin and slope (Table 3).
Newly studied sedimentary structures and sequences of tempestites in the Górno- field outcrop are described below. The textures and sedimentary structures in this quarry have been deformed by tectonics. Two layers show 

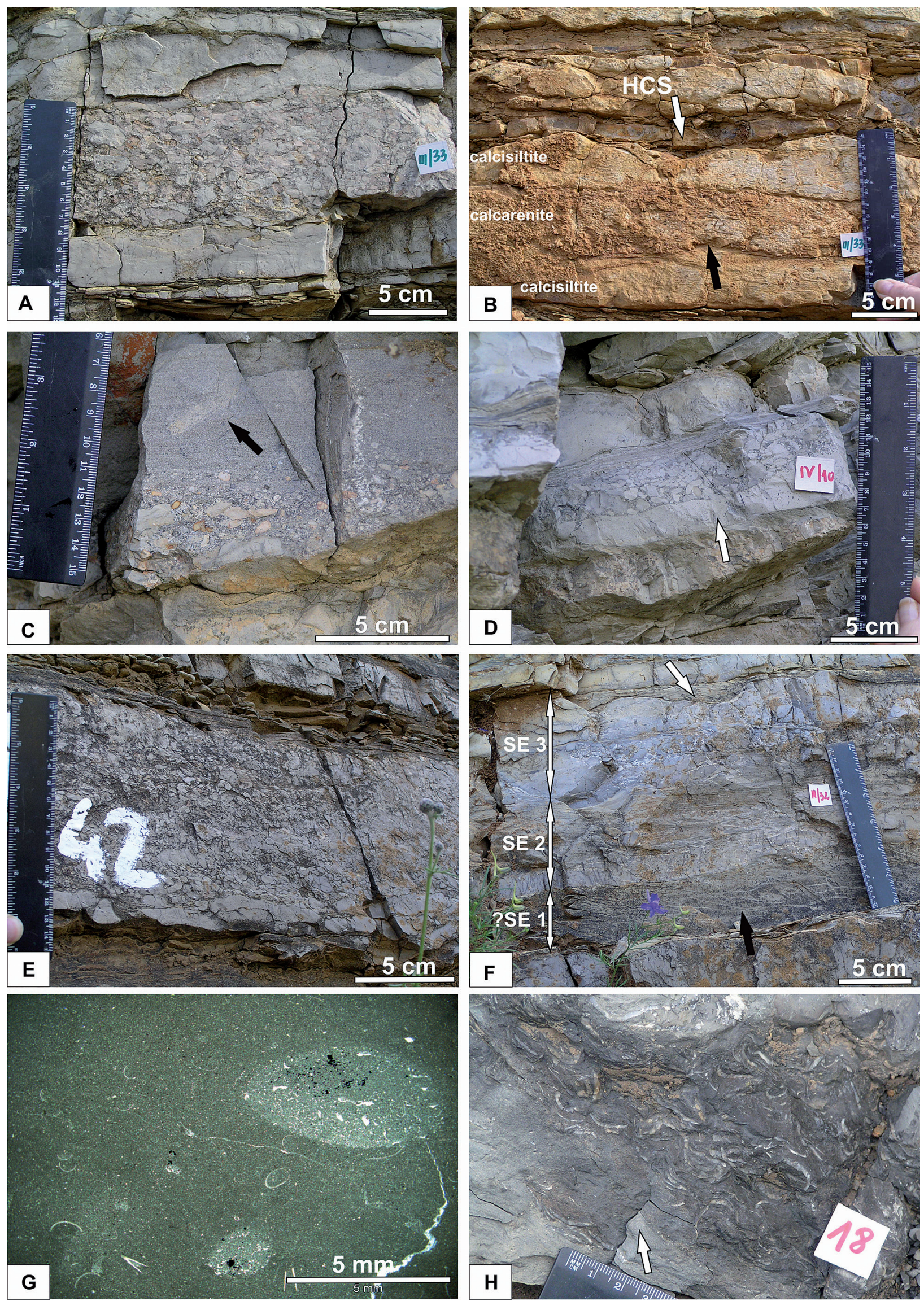
a proximal-to-distal trend of tempestites over a distance of only some $20 \mathrm{~m}$ (Fig. 4 A, B). Their lithologies change from NE to $S$ in the outcrop. Clast diameters, as well as thickness of coarsegrained layers decrease southwards. This is paired with appears hummocky structures and lamination. The sedimentological analysis of the succession shows at least 12 storm events (Figs. 3 and $4 \mathrm{~F}$ ).

The thickness and grain size of the tempestite layers often differs considerably from that of the under- and overlying layers (Fig. 4 A, B). The grain size of tempestite varies greatly and their distribution tends to be bimodal with a coarser-grained succession at the base and, separated by a kind of small hiatus, a finer-grained top part (Einsele \& Seilacher, 1991). The limestones are normally graded (Table 3; Figs 3 A-D and $4 \mathrm{C})$. However, the graded unit is often thin or lacking at all in relatively shallow water with high-energy conditions (Figs $3 \mathrm{E}$ and $4 \mathrm{~A}$ ); proximal tempestite facies have no muddy interbeds. Instead, amalgamation is characteristic. Examples of amalgamation are present, indeed, in the Górno-field (Fig. 4 D). These are thin calcirudite beds that have an erosional contact with the underlying micritic limestones. Locally, the tops of the calcirudites show horizontal or wavy lamination. As stressed by Duke (1985) (see also Dott \& Bourgeois, 1982; Walker et al., 1983; Einsele, 2000; Vierek, 2007b), these deposits reflect a decreasing wavy energy in comparison with the most proximal slope and characterised transitional (= normal) tempestites. In this site muddy intercalation increased.
Another feature of proximal tempestites is an erosional and sharp bottom contact with numerous sole marks (Fig. 3 D). Erosional surfaces vary in character - from flat, gently wavy to a distinctly $\mathrm{U}$ - or $\mathrm{V}$-shaped depressions (Fig. 4 A, B, D, F, H). Basal lags include millimetre- to centimetre-sized micritic spherical clasts and coarse flat-shaped intraclasts (Figs 3 A, B and $4 \mathrm{C}, \mathrm{E})$ as well as crinoid and brachiopod skeletal grains. The material is poorly or moderately sorted and shows several matrix- or grain-supported fabrics. Skeletal concentrations are common features in the upper part of the Szydłówek Beds in the Górno-Józefka quarry (Fig. $4 \mathrm{H}$; see also the coquina beds in Vierek, 2008). The graded coquinas composed of brachiopod shells and crinoid debris, characterised by erosional bases with sole marks, unstable position (convex-down) of shell and laminated tops, were deposited at approximately storm-wave base and are interpreted as tempestites.

On the tops of several layers, low-angle cross-lamination and hummocky cross-stratification (HCS) are characteristic features (Figs 3 A, C, D and 4 B, F); they indicate a high-energy current regime during deposition (e.g., Harms et al., 1975; Kreisa, 1981; Dott \& Bourgeois, 1982; Duke, 1985; Molina et al., 1997). The upper boundaries are also undulating (Fig. 3 E). At larger water depths, where the water is more quiet, HCS becomes less distinct and is replaced by parallel and horizontal lamination that may indicate unidirectional currents (cf. Flügel, 2004, p. 596). The horizontal lamination is often disturbed by bioturbation (Fig.

Fig. 4. The Górno-field.

A, B: Layer III/33 exhibiting a proximal-to-distal trend; the most proximal part (A) has a coarse-grained character and a grain-supported fabric; the tempestite in intermediate position (B) shows an erosional base (black arrow) and hummocky structure at the top (white arrow); the grain size of the tempestite differs clearly from that of the underand overlying layers.

C: Graded tempestite layer 7 (compare Fig. 3 D) showing a transition from bioclastic/conglomeratic to laminated micritic limestones; the arrow indicates bioturbation.

D: Breccia layer IV/10 with an erosional base (arrow) and horizontal lamination at the top; note irregular micritic intraclasts and grain-supported fabric.

E: Coarse-grained layer III/42 showing features of a most proximal, high-energy tempestite: grading, flat pebbles at the base and a grain-supported fabric.

F: Sedimentary structures supposed to be formed by ?three storm events of different intensity: the layers are amalgamated, but erosional bases between SE 1, SE 2 and SE 3 are visible; the black arrow indicates cross-lamination whereas the white arrow shows hummocky structure; note the abundance of intraclasts at the base of SE 3.

G: Bioturbated biomicrite background microfacies at Górno-field. Thin section II/22a.

$\mathbf{H}$ : Brachiopod shells arranged in random positions. The arrow indicates the erosional base; layer 18 in the Górno-Józefka outcrop. 
4 C). Distal layers are thin, fine-grained and mud-dominated. Their bases are sharp, planar, and lacking basal lag deposits. The tops are burrowed and bioturbated (Fig. $4 \mathrm{G}$ ).

\section{Discussion}

\subsection{Formation of tropical cyclones}

As summarized by Bourrouilh-Lejan et al. (2007), the areas and depth affected by strong hurricanes and waves are the first $30 \mathrm{~m}$ of the upper shelf as well as shallow-water platforms. Storm systems have E-W directed zones that can climatically be called hurricane, winter storm, and mixed hurricane-and-winter storm zones (see table 1 in Marsaglia \& Klein, 1983; see also Duke, 1985). At present, tropical hurricanes typically form in warm tropical seas (oceans) between $5^{\circ}$ and $10^{\circ} \mathrm{N}$ (and with a lesser extent S). Sporadically they occur in both hemispheres between $10^{\circ}$ and maximally $30^{\circ}$. Intense winter storms occur in turn, at middle and high latitudes (above $25^{\circ}$ ), forming along fronts between cold and warm air masses (see also Table 2).

Tropical hurricanes do not form over the equator (at least to $500 \mathrm{~km} \mathrm{~S}$ and N) due to the lack of influence of the Coriolis effect, which is required to develop wind rotation around the system (Nott, 2006, p. 78).

Several factors are necessary to generate hurricanes. The sea-surface temperature is the most important of them. It should be at least $27^{\circ} \mathrm{C}$ (Marsaglia \& Klein, 1983) and reach a depth of $50 \mathrm{~m}$ (Nyoumura \& Yamashita, 1984); only then hurricanes obtain sufficient energy. Nowadays, the strongest hurricanes are frequently formed at the western side of tropical seas and oceans, where warm water accumulates because of the movement of the ocean currents and eastern equatorial winds.

According to Bourrouilh-Lejan et al. (2007), the locations of hurricanes in tropical zones depend also on specific tropical biocenoses, such as coral reefs and green and red calcareous algae. Dynamic carbonate production (by the so-called carbonate factory) influences the precipitation of $\mathrm{CaCO}_{3}$ and, on the other hand, intensifies transfer of $\mathrm{CO}_{2}$ to the atmosphere (resulting in high atmospheric $\mathrm{CO}_{2}$ levels). A specific barrier, which maintains a high temperature over reef ecosystems, is thus formed. However, study of the atmospheric $\mathrm{CO}_{2}$ concentrations proves that these are not consistent with climate warming during the Frasnian. The GEOCARB III model (Berner \& Kothavala, 2001) and data from Simon et al. (2007) indicate a decrease in $p \mathrm{CO}_{2}$ during the Devonian, from 2000 ppm(v) in the Early Devonian to 900 $\operatorname{ppm}(v)$ in the Middle Devonian, and do not show an increase during the Frasnian.

To sum up, the palaeoclimate conditions with average temperatures reaching about 30 ${ }^{0} \mathrm{C}$, and the palaeogeographical position of the $\mathrm{HCM}$ region in the Late Devonian between $5^{\circ}$ and $10^{\circ} \mathrm{S}$ favoured influence of tropical hurricanes on the sedimentary record of carbonates. The carbonate platform of the HCM is a reefand shoal-rimmed isolated platform with a relatively steep margin (Szulczewski, 1995; Vierek, 2007b). On such platforms, as on the modern Bahama Banks, intensive storm waves are particularly important in controlling depositional facies along the platform margins. The platform-margin reefs are partly isolated from full-marine conditions and form diverse environments. This results in a variety of carbonate deposits and in the presence of layers characterised by diverse sedimentary structures, as described above.

\subsection{Tsunamis in the Late Devonian of the HCM region}

Were tsunamis possible in the Late Devonian of the HCM region? Such an event must be considered fairly hypothetical; it has been suggested only by Kaźmierczak \& Goldring (1978), but the sedimentological record does not support this hypothesis.

The shelf of Laurussia was characterised in the Late Devonian by an extensional regime. Subsidence successively increased and the Late Devonian epicontinental succession indicates continuous but punctuated drowning of the carbonate platform, which process became completed during the Visean (Szulczew- 
ski, 1995; Szulczewski et al., 1996). Carbonate sedimentation of the study area then became controlled primarily by eustatic sea-level fluctuations, local tectonics and episodic subsidence (e.g., Narkiewicz, 1988) that might have caused tsunamis under favourable conditions. It should be realised, however, that tsunamis generated by earthquakes are extremely rare during extensional tectonics (cf. Kulberg et al., 2001). Even if tectonic activity was low, slope failure of the Late Devonian isolated carbonated platform of the HCM region (see Vierek, 2007b) was, however, a possible trigger for tsunamis.

According to Racki \& Narkiewicz (2000), tectonic activity occurred the Early and Late Frasnian, the Frasnian/Famennian transition and the Middle Famennian. Synsedimentary tectonics was, however, of only limited magnitude and deformed the sediments only locally.

The rate of subsidence of the HCM region during the Late Devonian was relatively low (approx. $25 \mathrm{~m} / \mathrm{Ma}$ ) but increased during the Frasnian (Racki \& Narkiewicz, 2000). Additionally, the tectonic subsidence developed differently in the Łysogóry and Kielce regions and reflects locally block-related subsidence (Szulczewski, 1971; Racki \& Narkiewicz, 2000). Previous works by Preat \& Racki (1993) and Skompski \& Szulczewski (2000) imply that sedimentation in the HCM region during the Givetian and Frasnian was primarily controlled by local subsidence. The subsidence rate was low during the Late Devonian, however, thus diminishing the possibility of locally generated tsunamis. The then position of the study area on a shelf probably excludes the occurrence of a tsunami because the water was too shallow.

On the other hand, however, one can hypothesize that activity in a subduction zone generated occasional tsunamis (Fig. 2; see also fig. 11 in Golonka, 2007). Such a wave would, however, not reach the present-day area of the HCM. As the shelf sea was characterised during the Late Devonian by different types of morphology. Inshore/offshore carbonate platforms were present over most of its extent (e.g., Narkiewicz \& Racki, 1985; fig. 11 in Bełka et al., 1996; Narkiewicz, 1996); the HCM region was surrounded by shallow water and by stable el- evated areas: the Nida Platform, the Opatkowice Platform and the Cracow Platform to the South, and the elevated Lublin-Lviv area to the NE. Thus, tsunami energy should have been absorbed by these regions if tsunamites would have occurred.

Finally, tsunamis travel over long distances and affect large areas, so that their effects should be visible also in adjacent areas of the HCM region. The outer part of Laurussia shelf included an area from southern England through Belgium (Ardennes area), central Germany (Rhenish Massif and Harz Mountains) to southern Poland and Moravia (Bełka \& Narkiewicz, 2008).

Yet, Dreesen et al. (1988) do not exclude the possibility of the a local Late Devonian tsunami generated in the unstable area of the Ardennes-Rhenish Massif, where seismic and volcanic activity often accompanied tectonic movements along fault blocks. Hladil \& Kalvoda (1993) described episodes of intensive erosion and redeposition of breccia layers (Lowest Famennian, Moravia) and they connect this with a tsunami. The tectonic instability and volcanic activity in adjacent areas of the present-day HCM (the analysed part of the Laurussia shelf) thus seems related to the Frasnian/ Famennian boundary, rather than to a possible tsunami.

\section{Conclusions}

The palaeoclimate conditions, with average temperatures of about $28{ }^{\circ} \mathrm{C}$, and the palaeogeographical location of the Holy Cross Mountains region during the Late Devonian between $5^{\circ}$ and $10^{\circ} \mathrm{S}$ favoured the influence of tropical hurricanes on the sedimentary environment and deposition of carbonate rocks.

The sedimentological observations as well as sedimentary structures and context of tempestites in the Wietrznia succession, the Kostomłoty-Mogiłki quarry and the Górno outcrops are evidence of storm events in the Late Devonian of the HCM region (Table 3).

The palaeogeographical position of the $\mathrm{HCM}$ area in the middle part of a carbonate shelf (= shallow-water environment) and be- 
tween other platforms and elevated areas exclude the activity of tsunami waves, and thus of a tsunami-related sedimentary history of the limestones under study.

\section{References}

Aigner, T., 1985. Storm depositional systems. Lecture Notes in Earth Sciences 3, 1-174.

Bábek, O., Přikryl, T. \& Hladil, J., 2007. Progressive drowning of carbonate platform in the Moravo-Silesian Basin (Czech Republic) before the Frasnian/ Famennian event: facies, compositional variations and gamma-ray spectrometry. Facies 53, 293-316.

Bełka, Z. \& Narkiewicz, M., 2008. Devonian. [In:] T. McCann (Ed.): The geology of central Europe. Vol.1: Precambrian and Paleozoic. The Geological Society (London), 383-411.

Bełka, Z., Skompski, S. \& Soboń-Podgórska, J., 1996. Reconstruction of a lost carbonate platform on the shelf of Fennosarmatia: evidence from Visean polymictic debrites, Holy Cross Mountains, Poland. Geological Society, London, Special Publications 107, 315-329.

Berner, R.A. \& Kothavala, Z., 2001. GEOCARB III: a revised model of atmospheric $\mathrm{CO}_{2}$ over Phanerozoic time. American Journal of Science 301, 182-204.

Bourrouilh-Lejan, F.G., Beck, C. \& Gorsline, D.S., 2007. Catastrophic events (hurricanes, tsunami and others) and their sedimentary records: Introductory notes and new concepts for shallow water deposits. Sedimentary Geology 199, 1-11.

Cant, D.J., 1980. Storm-dominated shallow marine sediments of the Arisaig Group (Silurian-Devonian) of Nova Scotia. Canadian Journal of Earth Sciences 17, 120-131.

Carss, B.W. \& Carozzi, A.V., 1965. Petrology of Upper Devonian pelletoidal limestones, Arrow Canyon Range, Clark County, Nevada. Sedimentology 4, 197-224.

Della-Favera, J.C., 1982. Devonian storm- and tide-dominated shelf deposits, Parnaiba Basin, Brazil. American Association of Petroleum Geologists Bulletin 66, 1-562.

Devleeschouwer, X., Herbosch, A. \& Préat, A., 2002. Microfacies, sequence stratigraphy and clay mineralogy of a condensed deep-water section around the Frasnian/Famennian boundary (Steinbruch Schmidt, Germany). Palaeogeography, Palaeoclimatology, Palaeoecology 181, 171-193.

Dott, R.H. \& Bourgeois, J., 1982. Hummocky stratification: significance of its variable bedding sequences. Geological Society of America Bulletin 93, 663-680.

Dreesen, R., Paproth, E. \& Thorez, J., 1988. Events documented in Famennian sediments (Ardenne-Rhenish Massif, Late Devonian, NW Europe). [In]: N.J. McMillam, A.F. Embry \& D.J. Glass (Eds): Devonian of the world. Canadian Society of Petroleum Geologists 2, 295-308.
Duke, W.L., 1985. Hummocky cross-stratification, tropical hurricanes, and intense winter storms. Sedimentology 32, 167-194.

Einsele, G., 2000. Sedimentary basins - evolution, facies and sediment budget. Springer-Verlag (Berlin), 792 pp.

Einsele, G. \& Seilacher, A., 1991. Distinction of tempestites and turbidites. [In]: G. Einsele, W. Ricken \& A. Seilacher (Eds): Cycles and events in stratigraphy. Springer-Verlag (Berlin), 377-382.

Flügel, E., 2004. Microfacies of carbonate rocks - analysis, interpretation and application. Springer (Berlin), $976 \mathrm{pp}$.

Folk, R.L., 1973. Evidence for peritidal deposition of Devonian Caballos Novaculite, Marathon Basin, Texas. American Association of Petroleum Geologists Bulletin 57, 702-725.

George, A.D., Trinajstic, K.M. \& Chow, N., 2009. Frasnian reef evolution and palaeogeography, SE Lennard Shelf, Canning Basin, Australia. Geological Society, London, Special Publications 314, 73-107.

Goldring, R. \& Bridges, P.H., 1973. Sublitoral sheet sandstones. Journal of Sedimentary Petrology 43, 736-747.

Golonka, J., 2000. Cambrian-Neogene plate tectonic maps. Wydawnictwo Uniwersytetu Jagiellońskiego (Kraków), 125 pp.

Golonka, J., 2007. Phanerozoic paleoenvironment and paleolithofacies maps. Late Paleozoic. Geologia 33, 145-209.

Harms, J.C., Southard, J.B. \& Walker, R.G., 1982. Structures and sequences in clastic rocks. SEPM Short Course 9, 8-51.

Harms, J.C., Southard, J.B., Spearing, D.R. \& Walker, R.G., 1975. Depositional environments as interpreted from primary sedimentary structures and stratification sequence. SEPM Short Course 2, 1-161.

Hladil, J. \& Kalvoda, J., 1993. Devonian boundary intervals of Bohemia and Moravia. 'Global boundary events, an interdisciplinary conference' excursion guidebook (Kielce, 1993), 29-50.

Hofmann, M.H. \& Keller, M., 2006. Sequence stratigraphy and carbonate platform organization of the Devonian Santa Lucia Formation, Cantabrian Mountains, NWSpain. Facies 52, 149-167.

Joachimski, M.M., Breisig, S., Buggisch, W., Talent, J.A., Mawson, R., Gereke, M., Morrow, J.R., Day, J. \& Weddige, K., 2009. Devonian climate and reef evolution: insights from oxygen isotopes in apatite. Earth and Planetary Science Letters 284, 599-609.

Karim, K.H., 2007. Possible effect of storm on sediments of Upper Cretaceous Foreland Basin: a case study for tempestite in Tanjero Formation, Sulaimanyia Area, NE-Iraq. Iraqi Journal of Earth Science 7(2), 1-10.

Kaźmierczak, J. \& Goldring, R., 1978. Subtidal flat-pebble conglomerate from the Upper Devonian of Poland: a multiprovenant high-energy product. Geological Magazine 115, 359-366.

Kent, D.V. \& van der Voo, R., 1990. Paleozoic paleogeography from paleomagnetism of the Atlantic-bordering continents. Geological Society, London, Memoir 12, 49-56.

Kiessling, W., 2001. Paleoclimatic significance of Phanerozoic reefs. Geology 29, 751-754. 
Kiessling, W., Flügel, E. \& Golonka, J., 2003. Patterns of Phanerozoic carbonate platform sedimentation. Lethaia 36, 195-226.

Krebs, W., 1974. Devonian carbonate complexes of central Europe. SEPM Special Publication 18, 155-208.

Kreisa, R.D., 1981. Storm-generated sedimentary structures in subtidal marine facies with examples from the Middle and Upper Ordovician of Southwestern Virginia. Journal of Sedimentary Petrology 51, 823-848.

Kullberg, J.C., Olóriz, F., Marques, B., Caetano, P.S. \& Rocha, R.B., 2001. Flat-pebble conglomerates: a local marker for Early Jurassic seismicity related to syn-rift tectonics in the Sesimbra area (Lusitanian Basin, Portugal). Sedimentary Geology 139, 49-70.

Lewandowski, M., 2003. Assembly of Pangea: combined paleomagnetic and paleoclimatic approach. Advances in Geophysics 46, 199-236.

Lloyd, C.R., 1982. The Mid-Cretaceous earth: paleogeography; ocean circulation and temperature; atmospheric circulation. Journal of Geology 90, 393-415.

Małkowski, K., 1981. Upper Devonian deposits at Górno in the Holy Cross Mts. Acta Geologica Polonica 31, 223231.

Marsaglia, K.M. \& Klein, G.D., 1983. The paleogeography of Paleozoic and Mesozoic storm depositional systems. Journal of Geology 91,117-142.

Matyja, H., 1993. Upper Devonian of Western Pomerania. Acta Geologica Polonica 43, 27-94.

Molina, J.M., Ruiz-Ortiz, P.A. \& Vera, J.A., 1997. Calcareous tempestites in pelagic facies (Jurassic, Betic Cordilleras, Southern Spain). Sedimentary Geology 109, 95-109.

Monaco, P., 1992. Hummocky cross-stratified deposits and turbidites in some sequences of Umbria-Marche area (central Italy) during the Toarcian. Sedimentary Geology 77, 123-142.

Mount, J.F. \& Kidder, D., 1993. Combined flow origin of edgewise intraclast conglomerates: Sellick Hill Formation (Lower Cambrian), South Australia. Sedimentology 40, 315-329.

Myrow, P.M. \& Southard, J.B., 1996. Tempestite deposition. Journal of Sedimentary Research 66, 875-887.

Myrow, P.M., Tice, L., Archuleta, B., Clark, B., Taylor, J.F. \& Ripperdan, R.L., 2004. Flat-pebble conglomerate: its multiple origins and relationship to metre-scale depositional cycles. Sedimentology 51, 973-996.

Narkiewicz, M., 1978. Stratigraphy and facies development of the Upper Devonian in the Olkusz-Zawiercie area, Southern Poland. Acta Geologica Polonica 28, 415468 (in Polish with English summary).

Narkiewicz, M., 1988. Turning points in sedimentary development in the Late Devonian in southern Poland. Canadian Society of Petroleum Geologist Memoirs 14, 610-635.

Narkiewicz, M., 1996. Devonian stratigraphy and depositional environments in proximity of the Sub-Carpathian Arch: Lachowice 7 well, southern Poland. Geological Quarterly 40, 65-88.

Narkiewicz, M., 2007. Development and inversion of Devonian and Carboniferous basins in the eastern part of the Variscan foreland (Poland). Geological Quarterly 51, 231-256.

Narkiewicz, M. \& Racki, G., 1985. Elementy paleogeografii późnodewońskiej $\mathrm{w}$ rejonie przybrzeżnym szelfu południowej Polski [Major features of the Late Devonian palaeogegraphy in the near-shore shelf area of southern Poland; in Polish with English summary]. Przeglad Geologiczny 5, 271-274.

Nott, J., 2006. Extreme events - a physical reconstruction and risk assessment. Cambridge University Press, Cambridge, $297 \mathrm{pp}$.

Nyoumura, Y. \& Yamashita, H., 1984. On the central pressure change of tropical cyclones as a function of sea-surface temperature and land effect. Geophysical Magazine 41, 45-59.

Pisarzowska, A., 2009. Geochemia stabilnych izotopów węgla i tlenu na pograniczu franu dolnego i środkowego (górny dewon) na obszarze południowego szelfu Laurussii [Stable isotopes of carbon and oxygen of the Early - Middle Frasnian transition on the area of southern Laurussia shelf - in Polish]. Unpublished Ph.D. thesis, University of Silesia, Sosnowiec, 122pp.

Pisarzowska, A., Sobstel, M. \& Racki, G., 2006. Conodont-based event stratigraphy of the Early-Middle Frasnian transition on the South Polish carbonate shelf. Acta Palaeontologica Polonica 51, 609-646.

Pożaryski, W., 1986. Waryscyjski etap platformowego rozwoju tektonicznego Europy Środkowej [The Variscan stage of platform tectonical development of the Middle Europe - in Polish]. Przeglad Geologiczny 34, 117-127.

Pratt, B.R., 2002. Storms versus tsunamis: dynamic interplay of sedimentary, diagenetic, and tectonic processes in the Cambrian of Montana. Geology 30, 423-426.

Preat, A. \& Racki, G., 1993. Small-scale cyclic sedimentation in the Early Givetian of the Góry Świętokrzyskie Mountains: comparison with the Ardenne sequence. Annales Societatis Geologorum Poloniae 63, 13-31.

Pujol, F., Berner, Z. \& Stüben, D., 2006. Paleoenvironmental changes at the Frasnian/Famennian boundary in key European sections: chemostratigraphic constrains. Palaeogeography, Palaeoclimatology, Palaeoecology 240, 120-145.

Racki, G., 1985. Conodont biostratigraphy of the Givetian/Frasnian boundary beds at Kostomłoty in the Holy Cross Mts. Acta Geologica Polonica 35, 265-275.

Racki, G., 1993. Evolution of the bank to reef complex in the Devonian of the Holy Cross Mountains. Acta Palaeontologica Polonica 37, 87-182.

Racki, G. \& Bultynck, P., 1993. Conodont biostratigraphy of the Middle to Upper Devonian boundary beds in the Kielce area of the Holy Cross Mts. Acta Geologica Polonica 43, 1-25.

Racki, G. \& Narkiewicz, M., 2000. Tectonic versus eustatic controls of sedimentary development of the Devonian in the Holy Cross Mountains, Central Poland. Przeglad Geologiczny 48, 65-76 (in Polish with English summary).

Racki, G., Piechota, A., Bond, D. \& Wignall, P., 2004. Geochemical and ecological aspects of Lower Frasnian 
pyrite-ammonoid level at Kostomłoty (Holy Cross Mts, Poland). Geological Quarterly 48, 267-282.

Scotese, C.R. \& McKerrow, W.S., 1990. Revised world maps and introduction. Geological Society, London, Memoirs 12, 1-21.

Schieber, J., 1994. Evidence for high-energy events and shallow-water deposition in the Chattanooga Shale, Devonian, central Tennessee, USA. Sedimentary Geology 93, 193-208.

Simon, L., Godderish, Y., Buggisch, W., Strauss, H. \& Joachimski, M., 2007. Modeling the carbon and sulphur isotope composition of marine sediments: climate evolution during the Devonian. Chemical Geology 146, 19-38.

Skompski, S. \& Szulczewski, M., 2000. Lofer-type cyclothems in the Upper Devonian of the Holy Cross Mts. (central Poland). Acta Geologica Polonica 50, 393-406.

Stel, J.H., 1975. The influence of hurricanes upon the quiet depositional conditions in the Lower Emsian La Vid Shales of Colle (NW Spain). Leidse Geologische Mededelingen 49, 475-486.

Szulczewski, M., 1968. Slump structures and turbidites in Upper Devonian limestones of the Holy Cross Mts. Acta Geologica Polonica 17, 304-326.

Szulczewski, M., 1971. Upper Devonian conodonts, stratigraphy and facial development in the Holy Cross Mts. Acta Geologica Polonica 21, 1-129.

Szulczewski, M., 1977. Main facial regions in the Paleozoic of Holy Cross Mts. Przeglad Geologiczny 25, 428-432 (in Polish with English summary).

Szulczewski, M., 1995. Depositional evolution of the Holy Cross Mts. (Poland) in the Devonian and Carboniferous - a review. Geological Quarterly 39, 471-488.

Szulczewski, M., Bełka, Z. \& Skompski, S., 1996. The drowning of a carbonate platform: an example from the Devonian-Carboniferous of the southwestern Holy Cross Mountains, Poland. Sedimentary Geology $106,21-49$

Tait, J., Schätz, M., Bachtadse, V. \& Soffel, H., 2000. Palaeomagnetism and Palaeozoic palaeogeography of Gondwana and European terranes. Geological Society, London, Special Publications 179, 21-34.

Torsvik, T.H., Smethurst, M.A., Briden, J.C. \& Sturt, B.A., 1990. A review of paleomagnetic data from Europe and their palaeographical implications. Geological Society, London, Memoirs 12, 25-41.

Tsien, H.H., 1988. Devonian palaeogeography and reef development of northwestern and central Europe. $\mathrm{Ca}$ nadian Society of Petroleum Geologists 1, 341-358. van Loon, A.J., Han, Z., Han, Y., 2012. Slide origin of breccia lenses in the Cambrian of the North China Platform: new insight into mass transport in an epeiric sea. Geologos 18, 223-235.

van Loon, A.J., Han, Z. \& Han, Y., 2013. Origin of the vertically orientated clasts in brecciated shallow-marine limestones of the Chaomidian Formation (Furongian, Shandong Province, China). Sedimentology 60, 10591070.

Vierek, A., 2007a. Transitional reef-to-basin facies of Lower Frasnian limestones determined by microfacies analysis (Wietrznia, Holy Cross Mts, Poland). Facies 53, 141-155.

Vierek, A., 2007b. Storm-dominated deposition on a Frasnian carbonate platform margin (Wietrznia, Holy Cross Mts., Poland). Geological Quarterly 51, 307-318.

Vierek, A., 2008. Sedimentology of the upper part of the Szydłówek Beds. Przeglad Geologiczny 56, 848-856.

Vierek, A., 2010. Source and depositional processes of coarse-grained limestone event beds in Frasnian slope deposits (Kostomłoty-Mogiłki quarry, Holy Cross Mountains, Poland). Geologos 16, 153-168.

Vierek, A. \& Racki, G., 2011. Depositional versus ecological control on the conodont distribution in the Lower Frasnian fore-reef facies, Holy Cross Mountains, Poland. Palaeogeography, Palaeoclimatology, Palaeoecology 312, 1-23.

Walker, R.G., 1984. Facies models. $2^{\text {nd }}$ ed. Geosciences Canada Reprint Series 1, 1-318.

Walker, R.G., Duke, W.L. \& Leckie, D.A., 1983. Hummocky stratification: significance of its variable bedding sequences: discussion. Geological Society of America Bulletin 94, 1245-1249.

Whalen, M.T., Day, J., Eberli, G.P. \& Homewood, P.W., 2002. Microbial carbonates as indicators of environmental change and biotic crises in carbonate systems: examples from the Late Devonian, Alberta Basin, Canada. Palaeogeography, Palaeoclimatology, Palaeoeco$\log y$ 181, 127-151.

Witzke, B.J., 1990. Paleoclimatic constraints for Paleozoic palaeolatitudes of Laurentia and Euramerica. Geological Society, London, Memoirs 12, 257-265.

Ziegler, W. \& Sandberg, A.S., 1990. The Late Devonian standard conodont zonation. Courier Forschungsinstitut Senckenberg 121, 1-115.

Manuscript received: 24 January 2013

Revision accepted: 9 October 2013 